\title{
Long-Term Effects of Feeding Monensin on Methane Production in Lactating Dairy Cows
}

\author{
N. E. Odongo, ${ }^{\star 1}$ R. Bagg, $\ddagger$ G. Vessie,‡ P. Dick, $\ddagger$ M. M. Or-Rashid, ${ }^{\star}$ S. E. Hook, ${ }^{\star}$ J. T. Gray, $\dagger^{2}$ \\ E. Kebreab, ${ }^{*}$ J. France, ${ }^{\star}$ and B. W. McBride* \\ *Department of Animal and Poultry Science, and \\ †Department of Pathobiology, University of Guelph, Guelph, Ontario, Canada N1G 2W1 \\ †Elanco Animal Health, Division Eli Lilly Canada Inc., Guelph, Ontario, Canada N1G 4T2
}

\begin{abstract}
The objective of this study was to determine the longterm effects of feeding monensin on methane $\left(\mathrm{CH}_{4}\right)$ production in lactating dairy cows. Twenty-four lactating Holstein dairy cows $(1.46 \pm 0.17$ parity; $620 \pm 5.9 \mathrm{~kg}$ of live weight; $92.5 \pm 2.62 \mathrm{~d}$ in milk) housed in a tie-stall facility were used in the study. The study was conducted as paired comparisons in a completely randomized design with repeated measurements in a color-coded, double-blind experiment. The cows were paired by parity and days in milk and allocated to 1 of 2 treatments: 1 ) the regular milking cow total mixed ration (TMR) with a forage-to-concentrate ratio of 60:40 (control TMR; placebo premix) vs. a medicated TMR (monensin TMR; regular TMR + $24 \mathrm{mg}$ of Rumensin Premix/kg of dry matter) fed ad libitum. The animals were fed and milked twice daily (feeding at 0830 and 1300 h; milking at 0500 and $1500 \mathrm{~h}$ ) and $\mathrm{CH}_{4}$ production was measured prior to introducing the treatments and monthly thereafter for 6 mo using an open-circuit indirect calorimetry system. Monensin reduced $\mathrm{CH}_{4}$ production by $7 \%$ (expressed as grams per day) and by 9\% (expressed as grams per kilogram of body weight), which were sustained for 6 mo (mean, 458.7 vs. $428.7 \pm 7.75 \mathrm{~g} / \mathrm{d}$ and 0.738 vs. $0.675 \pm 0.0141$, control vs. monensin, respectively). Monensin reduced milk fat percentage by $9 \%$ ( 3.90 vs. $3.53 \pm 0.098 \%$, control vs. monensin, respectively) and reduced milk protein by $4 \%$ (3.37 vs. $3.23 \pm$ $0.031 \%$, control vs. monensin, respectively). Monensin did not affect the dry matter intake or milk yield of the cows. These results suggest that medicating a 60:40 forage-to-concentrate TMR with $24 \mathrm{mg}$ of Rumensin Premix/kg of dry matter is a viable strategy for reducing $\mathrm{CH}_{4}$ production in lactating Holstein dairy cows.
\end{abstract}

Received October 26, 2006.

Accepted November 21, 2006.

${ }^{1}$ Corresponding author: nodongo@uoguelph.ca

${ }^{2}$ Current address: Department of Microbiology, Des Moines University, 3200 Grand Ave., Ryan Hall 272, Des Moines, IA 50312-4198.
Key words: air emission, monensin, methane, dairy cow

\section{INTRODUCTION}

In recent years, there has been an increase in public concern over environmental damage originating from animal feeding operations. The increased concentration of greenhouse gases $\left(\mathrm{CO}_{2}, \mathrm{CH}_{4}\right.$, and $\left.\mathrm{N}_{2} \mathrm{O}\right)$ in the troposphere has been implicated in the consistent increase in atmospheric temperature and global warming over the last few decades (Intergovernmental Panel on Climate Change, 2001). The concentration of methane $\left(\mathrm{CH}_{4}\right)$ has increased at a rate of $10 \mathrm{~nL} / \mathrm{L}$ per yr $(1 \mathrm{~nL}=$ $10^{-9} \mathrm{~L}$ ) since the preindustrial revolution (Moss et al., 2000). Domesticated ruminants are estimated to produce about $80 \mathrm{Tg}$ of $\mathrm{CH}_{4}$ annually $(1 \mathrm{Tg}=1$ million metric tons), accounting for about $22 \%$ of $\mathrm{CH}_{4}$ emissions from human-related activities (NRC, 2002).

Methane is produced in ruminants as an unavoidable by-product of $\mathrm{OM}$ fermentation in the rumen, and it represents a significant energy loss to the host animal. Johnson and Johnson (1995) estimated that the energy lost as $\mathrm{CH}_{4}$ in ruminants can range from 2 to $12 \%$ of the gross energy intake. The rate of $\mathrm{CH}_{4}$ production from livestock is influenced by several factors, including the level of feed intake, type of dietary carbohydrate, feed processing, dietary addition of lipids or ionophores, and changes in ruminal microbial flora and microflora (Johnson and Johnson, 1995; NRC, 2002). Monensin is an ionophore approved for use in lactating dairy cows in several countries, including Australia, Argentina, Brazil, Canada, New Zealand, South Africa, and recently the United States. Monensin is used extensively to manipulate ruminal fermentation and thereby improve feed efficiency (Russell and Strobel, 1989). Monensin is a carboxylic polyether ionophore antibiotic that is produced by fermentation of Streptomyces cinnamonensis (Russell, 2002). Benefits of feeding ionophores to lactating dairy cows include a shift in the acetateto-propionate ratio toward more propionate and an as- 
sociated decrease in methanogenesis (Russell and Houlihan, 2003), increased milk production (McGuffey et al., 2001), antiketogenic effects (Duffield and Bagg, 2000), improved BCS (Sauer et al., 1998; Duffield et al., 1999), control of legume bloat (Maas et al., 2002), and reduced risk of acidosis by inhibiting lactic acid production in the rumen (Tung and Kung, 1993; McGuffey et al., 2001).

However, studies reporting reductions in ruminal methanogenesis with ionophore supplementation have varied with respect to the extent of the reduction and persistence of the response (Carmean and Johnson, 1990; Mbanzamihigo et al., 1996; Sauer et al., 1998). For example, Sauer et al. (1998) reported that ruminal microflora in cows that had previously received monensin seemed to have undergone some adaptive changes and no longer responded to monensin with repeat monensin supplementation; however, animals and treatments were confounded in that study. Guan et al. (2006) found that the 27 to $30 \%$ reductions in $\mathrm{CH}_{4}$ production with ionophore supplementation were short-lived. In the study by Guan et al. (2006), $\mathrm{CH}_{4}$ production levels returned to the preionophore supplementation level after 2 to $4 \mathrm{wk}$, depending on the energy content of the diet. The objective of the present study was to determine the long-term effects of feeding monensin on $\mathrm{CH}_{4}$ production in lactating dairy cows.

\section{MATERIALS AND METHODS}

\section{Animals and Treatments}

Twenty-four lactating Holstein dairy cows (1.46 \pm 0.17 parity; $620 \pm 5.9 \mathrm{~kg}$ of live weight; $92.5 \pm 2.62 \mathrm{DIM}$, mean $\pm \mathrm{SE}$ ) housed in a tie-stall facility at the Elora Dairy Research Centre, University of Guelph (Guelph, ON, Canada), were used in the study. Animals were cared for and handled in accordance with the Canadian Council on Animal Care regulations, and the University of Guelph Animal Care Committee reviewed and approved the experiment and all procedures carried out in the study.

The study was conducted as paired comparisons in a completely randomized design with repeated measurements in a color-coded double-blind experiment. The cows were paired by parity and DIM and allocated to 1 of 2 treatments: 1) the regular Elora Dairy Research Centre milking cow TMR with a forage-to-concentrate ratio of 60:40 introduced at calving (control; placebo premix) or 2) a medicated TMR (monensin; regular TMR + $24 \mathrm{mg}$ of Rumensin Premix (Elanco Animal Health, Division Eli Lilly Canada Inc., Guelph, ON, Canada)/kg of DM. The Rumensin Premix was incorporated into soyhulls, which acted as the carrier, whereas the placebo contained only soyhulls. The placebo and
Table 1. Ingredients and chemical composition (DM basis) of the diet TMR

Ingredient composition, \% (DM basis)

Corn silage

Haylage

High-moisture corn

Second-cut alfalfa hay

TMR dairy supplement ${ }^{1}$

Chemical composition, \%, DM basis

$\mathrm{DM}, \%$

$\mathrm{CP}(\mathrm{N} \times 6.25)$

Soluble protein $\%$

Soluble protein, \% of CP

Acid detergent protein, $\%$ of $\mathrm{CP}$

Neutral detergent protein, $\%$ of $\mathrm{CP}$

Undegradable intake protein, $\%$ of $\mathrm{CP}$ $\mathrm{ADF}$

$\mathrm{NDF}$

$\mathrm{NFC}^{2}$

Lignin, \% NDF

Calcium

Phosphorus

Potassium

Magnesium

Sodium

Fat

Ash

$\mathrm{NE}_{\mathrm{L}}, \mathrm{Mcal} / \mathrm{kg}$

${ }^{1}$ Contained ( $\mathrm{g} / \mathrm{kg}$ of DM): $48 \%$ soybean meal, 285 ; high-protein corn gluten meal, 150; canola meal, 100; roasted soybean (whole), 100; soyhulls (ground), 55.5 ; fish meal (herring), 50 ; beet pulp, 50; sodium bicarbonate, 39; calcium carbonate (limestone), 38; dicalcium phosphate, 33; fine salt, 25; golden flake, 20; molasses (in pelleter), 20; urea, 15; magnesium oxide $(56 \% \mathrm{Mg})$, 8.9 ; organic ruminant Micro Premix (Floradale Feed Mill Limited, Floradale, ON, Canada), 6.3; sulfur flour 99.5\%, 3.2; Yea-Sacc ${ }^{1026}$ (Alltech Inc., Nicholasville, KY), 0.9; Rovimix H-2 (DSM Nutritional Products, Inc., Parsippany, NJ), 0.2 . Placebo premix ( $\mathrm{g} / \mathrm{kg}$ of $\mathrm{DM})$ : soyhulls, 1,000 . Medicated premix (g/kg of DM): Rumensin Premix (Elanco Animal Health, Division Eli Lilly Canada Inc., Guelph, ON, Canada), 2.56 g; soyhulls 997.44 g.

${ }^{2}$ Nonfiber carbohydrates were calculated as NFC $=100-(\% \mathrm{NDF}$ $+\% \mathrm{CP}+\%$ fat $+\%$ ash $)$.

monensin premixes were mixed with the TMR each morning. The dietary composition and chemical analysis are presented in Table 1.

Cows were fed ad libitum, allowing for 5 to $10 \%$ refusal. The feed was offered twice daily at 0830 and 1300 $\mathrm{h}$, and the cows had unlimited access to fresh water. The cows were milked in their stalls twice daily at 0500 and 1500 h. On $\mathrm{CH}_{4}$ measurement days, milk samples were collected from morning and afternoon milkings and preserved with 2-bromo-2-nitropropane-1-2-diol. The milk samples were pooled daily based on milk yield, and the pooled samples were immediately submitted to the Central Milk Testing Laboratory (Laboratory Services Division, University of Guelph) for compositional analysis.

\section{Measurements of Methane Production}

Methane production from the cows was measured prior to introducing the treatments and monthly there- 
after for 6 mo using an open-circuit indirect calorimetry system, as described by Kelly et al. (1994) and updated by Odongo et al. (2007). Briefly, the calorimetry unit was based on 2 separate but linked sampling lines attached to 2 airtight ventilated head-hoods. The hoods were large enough to allow the animals to move their heads without restriction such that the animals could stand or lie down in the stanchions with their head remaining in the hoods. The animal's head was enclosed in the hood using a sleeve around the animal's neck to minimize air leakage. The cows had free access to feed and water in the hood. Outside air was circulated around the animal's head, mouth, and nose through the sleeve, and a subsample of the expired air was passed through Drierite (W. A. Hammond Drierite Co., Ltd., Xenia, $\mathrm{OH}$ ) to remove water vapor and was delivered at positive pressure to inline analyzers. Methane and $\mathrm{CO}_{2}$ concentrations in samples of inspired and expired air were measured using a nondispersive infrared $\mathrm{CH}_{4} / \mathrm{CO}_{2}$ analyzer (Servomex Xentra 4100 gas purity analyzer; Servomex Group Ltd., Crowborough, East Sussex, UK), and the concentration of $\mathrm{O}_{2}$ was measured using a paramagnetic $\mathrm{O}_{2}$ analyzer (Servomex Xentra 4100 gas purity analyzer; Servomex Group Ltd.) with a response time of $<12 \mathrm{~s}$ for the $\mathrm{O}_{2}$ analyzer and $<20 \mathrm{~s}$ for the $\mathrm{CH}_{4} / \mathrm{CO}_{2}$ analyzer. A Foxboro 823 IFO integral flow orifice with cell transmitter (Invensys Systems, Inc., Foxboro, MA) was used to measure the airflow rate. The analyzers were calibrated each week as described by McLean and Tobin (1987).

\section{Chemical Analysis}

Dry matter intakes were monitored daily throughout the experiment. Representative samples of the TMR were collected from the data ranger (American Calan, Northwood, NH) 3 times per week and stored at $-20^{\circ} \mathrm{C}$ until analyzed. Orts from individual cows were weighed each morning prior to feeding, and representative samples were collected and stored at $-20^{\circ} \mathrm{C}$ until analyzed. The TMR and orts were analyzed for DM by oven-drying at $60^{\circ} \mathrm{C}$ for $48 \mathrm{~h}$ (method 930.15; AOAC, 1990). The dried TMR samples were then ground to pass through a 1-mm screen (Wiley mill, Arthur H. Thomas, Philadelphia, PA) and chemical composition was determined in duplicate at a commercial laboratory (Agri-Food Laboratories, Guelph, ON, Canada). Analytical DM content was determined by oven-drying at $135^{\circ} \mathrm{C}$ for $2 \mathrm{~h}$ (method 3.002; AOAC, 1990), OM by ashing at $500^{\circ} \mathrm{C}$ for $16 \mathrm{~h}$ (method 942.05; AOAC, 1990), CP using a Leco FP 428 nitrogen analyzer (Leco Corporation, St. Joseph, MI; method 4.2.08; AOAC, 1990), and protein fractions as described by Roe et al. (1990). The samples were also analyzed for ether extract (method 920.39; AOAC,
1990), ADF (method 973.18c; AOAC, 1990), and NDF (Van Soest et al., 1991) using $\alpha$-amylase (Sigma no. A3306; Sigma Chemical Co., St. Louis, MO), sodium sulfite corrected for ash concentration adapted for an Ankom 200 fiber analyzer (Ankom Technology, Fairport, NY), lignin (method 973.18; AOAC 1990), and Ca, $\mathrm{P}, \mathrm{K}, \mathrm{Mg}$, and $\mathrm{Na}$ by inductively coupled plasma spectroscopy (method 945.46; AOAC 1990). Milk samples were analyzed for $\mathrm{CP}$, fat, and lactose using a nearinfrared analyzer (Foss System 4000, Foss Electric, Hillerød, Denmark).

\section{Statistical Analysis}

The repeated monthly measurements of DMI, milk yield, milk composition, and $\mathrm{CH}_{4}$ production were analyzed using the PROC MIXED procedure of SAS (v. 9.1; SAS Inst., Inc., Cary, NC) using the model

$$
\mathrm{Y}_{\mathrm{ij}}=\mu+\alpha_{\mathrm{i}}+\beta_{\mathrm{j}}+\alpha \beta_{\mathrm{ij}}+\varepsilon_{\mathrm{ij}},
$$

where $Y_{i j}$ is the dependent variable, $\mu$ is the overall mean, $\alpha_{\mathrm{i}}$ is the effect of treatment $(\mathrm{i}=1,2), \beta_{\mathrm{j}}$ is the effect of pair $(\mathrm{j}=1,2, \ldots, 12), \alpha \beta_{\mathrm{ij}}$ is the effect of a treatment $\times$ pair interaction $\left({ }_{i j}=1,2, \ldots, 24\right)$, and $\varepsilon_{i j}$ is the random residual error. To determine time-dependent changes and interactions between time and treatment, the effects of control vs. monensin over time were evaluated using orthogonal contrasts. Baseline DMI was used as the covariate and effects were considered significant at a probability of $P<0.05$. Data are expressed as mean \pm standard error of the mean, which represents the pooled standard error for the model.

\section{RESULTS AND DISCUSSION}

Dry matter intake, milk yield, milk composition, and $\mathrm{CH}_{4}$ production from lactating dairy cows fed a control vs. monensin-treated TMR are presented in Table 2. Monensin intake ranged from 307.3 to $708.1 \mathrm{mg} / \mathrm{cow}$ per day. All animals adapted easily to confinement in the hoods during $\mathrm{CH}_{4}$ measurement, and there were no indications of discomfort or stress to the animals. Monensin had no $(P>0.05)$ effect on DMI and milk yield of the cows (Table 2). Several other studies have also reported no differences in DMI (e.g., Van der Werf et al., 1998; Phipps et al., 2000; AlZahal et al., 2005) and milk yield (Duffield et al., 1999; Phipps et al., 2000) between control and monensin-treated cows. Monensin reduced $(P<0.05) \mathrm{CH}_{4}$ production by $7 \%$, expressed as grams per day, and by $9 \%$, expressed as grams per kilogram of BW, compared with the control group, which was sustained for 6 mo (Table 2 and Figure 1). The 7 or $9 \%$ reduction in $\mathrm{CH}_{4}$ production, expressed as 
Table 2. Effects of a control vs. monensin-treated TMR on DMI, milk yield, milk composition, and methane $\left(\mathrm{CH}_{4}\right)$ production from lactating dairy cows

\begin{tabular}{|c|c|c|c|c|c|c|}
\hline \multirow[b]{2}{*}{ Response $^{1}$} & \multicolumn{2}{|c|}{ TMR } & \multirow[b]{2}{*}{ SEM } & \multicolumn{3}{|c|}{ Time, $P$-value } \\
\hline & Control & Monensin & & Linear & Quadratic & Cubic \\
\hline DMI, kg/d & 19.7 & 19.1 & 0.36 & 0.24 & 0.58 & 0.03 \\
\hline Milk yield, kg/d & 26.2 & 25.9 & 0.64 & $<0.01$ & 0.06 & 0.21 \\
\hline Milk fat, \% & $3.90^{\mathrm{a}}$ & $3.53^{b}$ & 0.098 & 0.30 & 0.11 & 0.99 \\
\hline Milk protein, $\%$ & $3.37^{\mathrm{a}}$ & $3.23^{\mathrm{b}}$ & 0.031 & $<0.01$ & 0.10 & 0.38 \\
\hline Methane production, g/d & $458.7^{\mathrm{a}}$ & $428.7^{\mathrm{b}}$ & 7.75 & 0.03 & $<0.01$ & $<0.01$ \\
\hline Methane production, $\mathrm{g} / \mathrm{kg}$ of $\mathrm{BW}$ & $0.738^{\mathrm{a}}$ & $0.675^{\mathrm{b}}$ & 0.0141 & 0.06 & $<0.01$ & $<0.01$ \\
\hline Methane production, g/g of $\mathrm{NDFI}^{2}$ & 0.069 & 0.066 & 0.0016 & 0.48 & 0.02 & $<0.01$ \\
\hline
\end{tabular}

${ }^{\mathrm{a}, \mathrm{b}}$ Means within a row with different superscripts differ $(P<0.05)$.

${ }^{1}$ Means of 12 cows per treatment.

${ }^{2} \mathrm{NDFI}=$ neutral detergent fiber intake.

grams per day or grams per kilogram of $\mathrm{BW}$ in the current study, was within the range of slight to $25 \%$ previously reported for lactating Holstein dairy cows (Johnson and Johnson, 1995). It has been suggested that the decrease in methanogenesis is not due to a direct effect of monensin on methanogenic bacteria (Van Nevel and Demeyer, 1977), but rather results from a shift in the bacterial population from gram-positive to gram-negative organisms, with a concurrent shift in the fermentation from acetate to propionate (Chen and Wolin, 1979). Wilkerson et al. (1995) reported a mean $\mathrm{CH}_{4}$ production for lactating Holsteins (weighing 600 $\mathrm{kg}$ or more) of $338 \mathrm{~g} / \mathrm{d}$, with minimum and maximum values of 105 and $520 \mathrm{~g} / \mathrm{d}$. Sauer et al. (1998) reported a mean $\mathrm{CH}_{4}$ production of $425 \pm 15 \mathrm{~g} / \mathrm{d}$ for mature, lactating Holsteins with BW of $600 \mathrm{~kg}$ or more and producing $29 \pm 1.5 \mathrm{~kg}$ of milk/d. A similar mean $\mathrm{CH}_{4}$ production $(420 \pm 16.3 \mathrm{~g} / \mathrm{d})$ for untreated TMR was reported by Odongo et al. (2007), in agreement with the current study. McGinn et al. (2004) reported a 9\% reduction in $\mathrm{CH}_{4}$ production corrected for differences in energy intake with monensin in beef cattle.

In the present study, monensin reduced $(P<0.05)$ milk fat percentage by $9 \%$ (3.90 vs. $3.53 \pm 0.098 \%$, control vs. monensin, respectively) and reduced $(P<0.05)$ milk protein percentage by $4 \%$ (3.37 vs. $3.24 \pm 0.031 \%$, control vs. monensin, respectively). A number of studies have shown that monensin depresses milk fat percentage (Phipps et al., 2000; Duffield et al., 2003; AlZahal et al., 2005). In a summary of 11 publications, McGuffey et al. (2001) found that cows fed monensin had higher average milk yields $(1.3 \mathrm{~kg} / \mathrm{d})$ and lower milk fat contents (3.98\% vs. $3.78 \%)$. The milk-fat-depressing effect of monensin has been attributed to the reduced ruminal production of acetate and butyrate (Dye et al., 1988; Van der Werf et al., 1998), the inhibition of ruminal biohydrogenation of long-chain fatty acids (Fellner et al., 1997), and the enhanced supply of trans-10, cis12 CLA to the mammary gland (Griinari et al., 1998;
Jenkins et al., 2003; Benchaar et al., 2006), which has been shown to be a potent inhibitor of milk fat synthesis in dairy cows (Baumgard et al., 2000). However, other studies have not shown milk fat depression following monensin administration (e.g., Lean et al., 1994; Duffield et al., 1999). The milk protein content of monensintreated cows was lower than for control cows, in agreement with Hayes et al. (1996), Green et al. (1999), and Phipps et al. (2000), although other studies (e.g., Ramanzin et al., 1997; Benchaar et al., 2006) have not shown a protein response with monensin.

Methane production $(\mathrm{g} / \mathrm{d}, \mathrm{g} / \mathrm{kg}$ of $\mathrm{BW}$, or $\mathrm{g} / \mathrm{g}$ of NDF intake) presented cubically $(P<0.05)$ over the course of the trial (Table 2 and Figures 1 and 2, respectively). Methane production per kilogram of milk and milk protein percentage increased linearly $(P<0.0001)$ with time, DMI presented cubically $(P=0.033)$ with time, and milk yield declined linearly $(P<0.0001)$ with time. Time had no $(P>0.05)$ effect on milk fat percentage (Table 2). Figure 1 shows that monensin reduced and sustained a 7 to $9 \%$ reduction in $\mathrm{CH}_{4}$ production $(\mathrm{g} / \mathrm{d}$ and $\mathrm{g} / \mathrm{kg}$ of BW) for $6 \mathrm{mo}$, in agreement with other previous studies (e.g., Davies et al., 1982; Mbanzamihigo et al., 1995, 1996; Rogers et al., 1997) that have shown 40 - to $240-\mathrm{d} \mathrm{CH}_{4}$ reductions as long as monensin was fed.

However, other studies (Rumpler et al., 1986; Johnson and Johnson, 1995; Sauer et al., 1998; Guan et al., 2006) have shown that the reduction in $\mathrm{CH}_{4}$ production was not persistent. When measured after up to $30 \mathrm{~d}$ of supplementation, levels of $\mathrm{CH}_{4}$ production returned to the preionophore supplementation levels, likely because of an ability of the ruminal microflora to adapt to the ionophore (Johnson and Johnson, 1995). Guan et al. (2006) found that although the extent of monensinmediated suppression of $\mathrm{CH}_{4}$ production in yearling steers was similar for both high- and low-concentrate diets, the duration of suppression was longer when animals were fed a low-concentrate diet than when ani- 

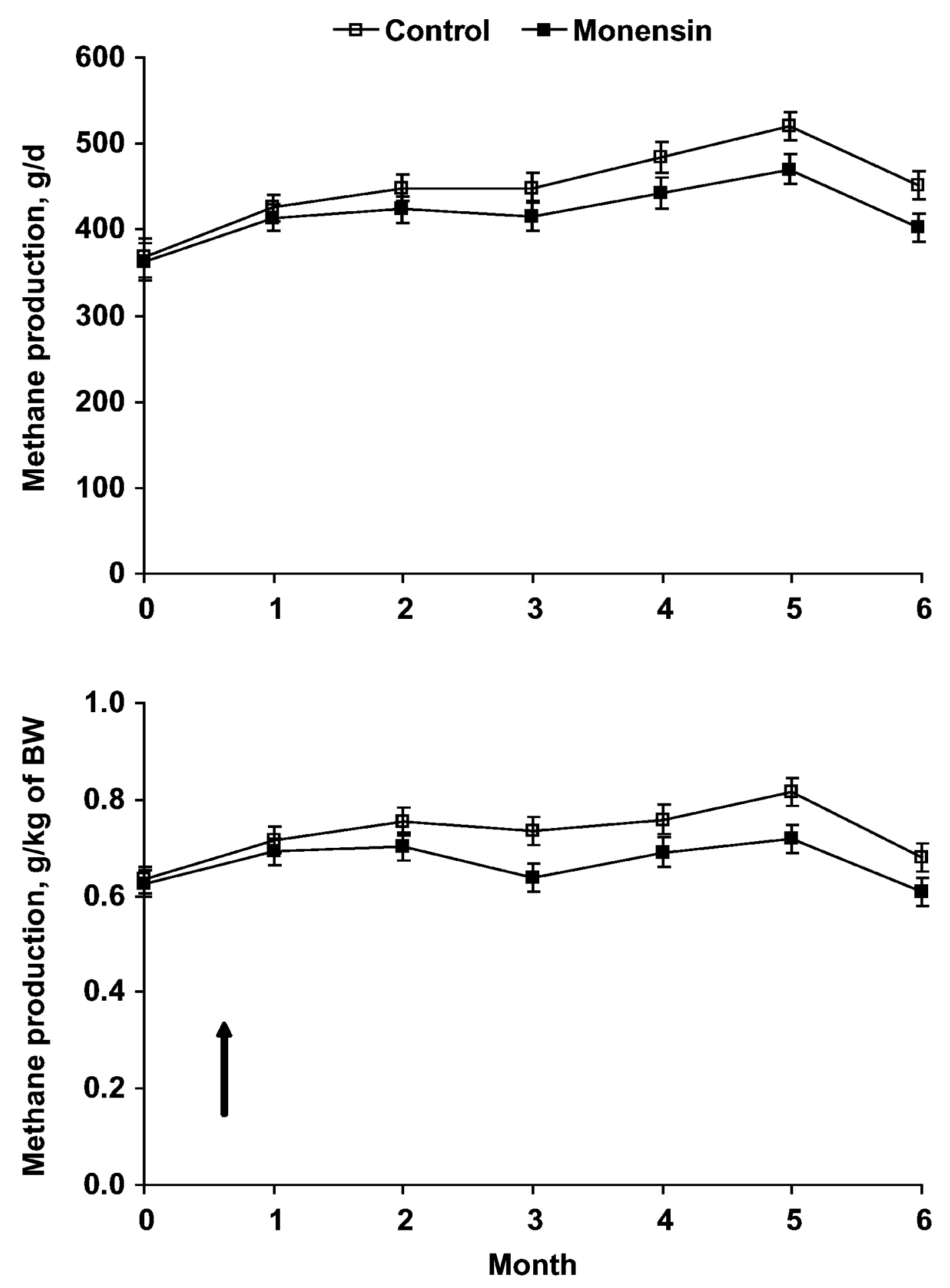

Figure 1. Effects of a control (- $\square$-) vs. monensin (-口-)-treated TMR on $\mathrm{CH}_{4}$ production in lactating dairy cows for 6 mo. Arrow indicates the introduction of monensin. Standard errors of the mean for $\mathrm{CH}_{4}$ production (expressed as $\mathrm{g} / \mathrm{d}$ or $\mathrm{g} / \mathrm{kg}$ of BW) were 24.03 and 0.029 , respectively.

mals were fed a high-concentrate diet. This is in agreement with Johnson et al. (1997), who suggested that the adaptation response for methanogenesis might be related to the composition of the diet fed in terms of available energy. In the current study, methane production ( $\mathrm{g} / \mathrm{g}$ of NDF intake) did not differ between treat- 


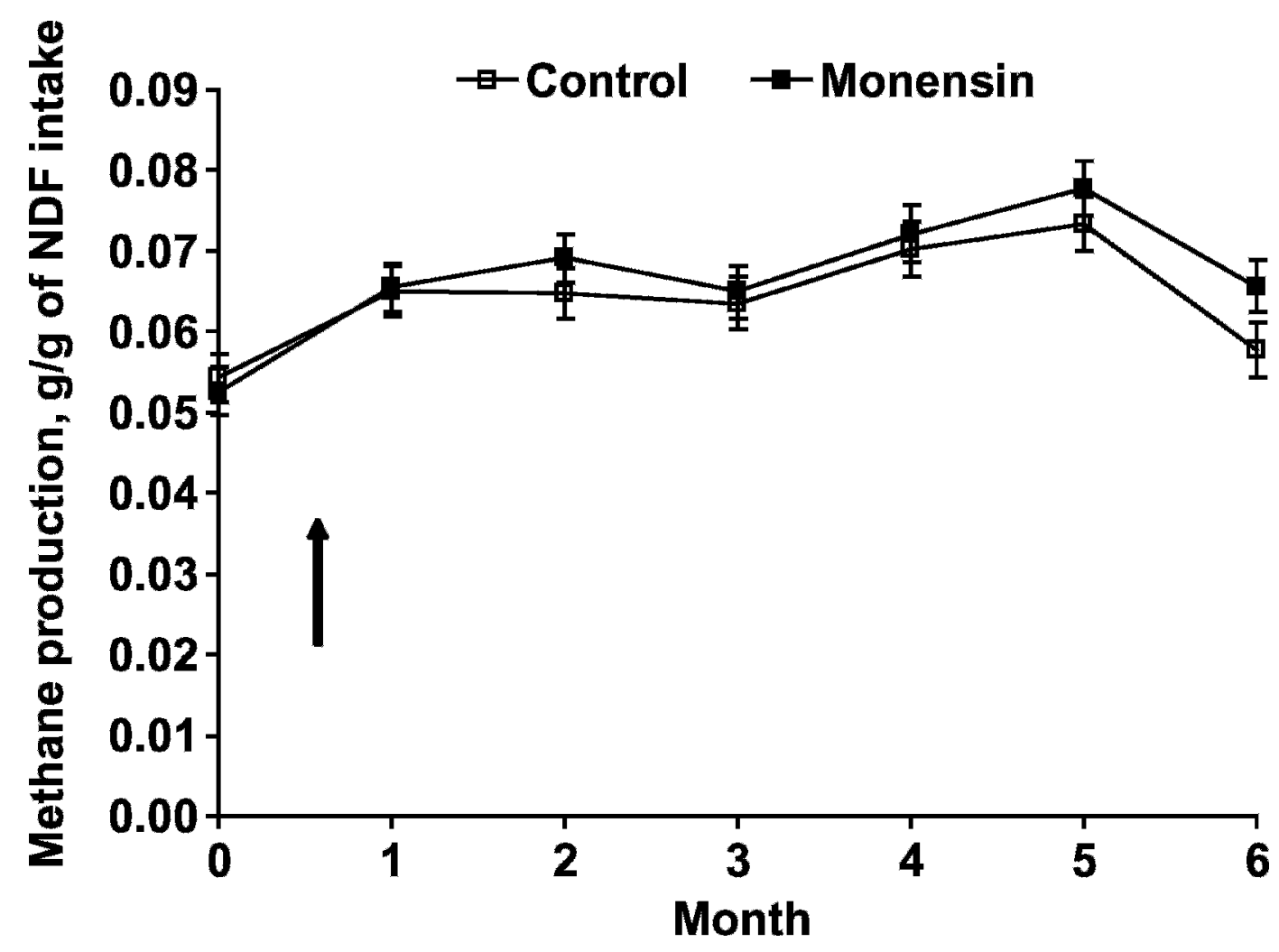

Figure 2. Effects of a control (- $\square$-) vs. monensin (-口-)-treated TMR on methane $\left(\mathrm{CH}_{4}\right)$ production (g/g of NDF intake) in lactating dairy cows for 6 mo. Arrow indicates the introduction of monensin. Standard error of the mean for $\mathrm{CH}_{4}$ production was 0.0016 .

ments, likely because the forage-to-concentrate ratio of the TMR was maintained at 60:40 throughout the trial. Another possible explanation for these contrasting findings is that different methods were used to assess $\mathrm{CH}_{4}$ production (Johnson and Johnson, 1995). For example, even though the average daily $\mathrm{CH}_{4}$ emissions predicted from the sulfur hexafluoride $\left(\mathrm{SF}_{6}\right)$ technique $(11.6 \pm 0.7 \mathrm{~L} / \mathrm{h})$ were similar to those measured using open-circuit respiration calorimetry $(12.9 \pm 0.7 \mathrm{~L} / \mathrm{h}$; Johnson et al., 1994), variation among animals has been shown to be larger in the $\mathrm{SF}_{6}(11.7 \%)$ than in the calorimetry technique $(0.1 \%$; Boadi et al., 2001), suggesting that more animals per treatment and sufficient collection days per animal are required to minimize day-today variation and to improve the power of the test to detect a meaningful effect, given the sample size, test size (significance level), and standardized effect size (Steel et al., 1997).

\section{CONCLUSIONS}

Agriculture in Canada contributes approximately 7.3\% of the total Canadian greenhouse gas emissions, of which $43.6 \%$ is $\mathrm{CH}_{4}$ from enteric fermentation (Environment Canada, 2006). These results suggest that the use of monensin in dairy cow rations with $60 \%$ forage is a viable strategy for reducing $\mathrm{CH}_{4}$ production. Mitigating $\mathrm{CH}_{4}$ emissions from dairy cattle will have longterm environmental benefits in terms of reducing the contribution of animal agriculture to greenhouse gas emissions.

\section{ACKNOWLEDGMENTS}

The authors thank Laura Wright and the staff at the Elora Dairy Research Centre, University of Guelph, for their technical assistance and Elanco Animal Health, Division Eli Lilly Canada Inc., for financial support. We also acknowledge the continued support received from the Ontario Ministry of Agriculture, Food and Rural Affairs and the Natural Sciences and Engineering Research Council of Canada (BWM).

\section{REFERENCES}

AlZahal, O., N. E. Odongo, T. Mutsvangwa, F. Duffield, R. Bagg, G. Vessie, and B. W. McBride. 2005. Interaction between monensin and dietary soy oil inclusion on milk fat yield in lactating cows. J. Dairy Sci. 88(Suppl. 1):183 (Abstr.)

AOAC. 1990. Official Methods of Analysis. 15th ed. AOAC, Arlington, VA. 
Baumgard, L. H., B. A. Corl, D. A. Dwyer, A. Saebo, and D. E. Bauman. 2000. Identification of the conjugated linoleic acid isomer that inhibits milk fat synthesis. Am. J. Physiol. 278:R179-R184.

Benchaar, C., H. V. Petit, R. Berthiaume, T. D. Whyte, and P. Y. Chouinard. 2006. Effects of addition of essential oils and monensin premix on digestion, ruminal fermentation, milk production, and milk composition in dairy cows. J. Dairy Sci. 89:4352-4364.

Boadi, D. A., K. M. Wittenberg, and A. D. Kennedy. 2001. Validation of the sulphur hexafluoride (SF6) tracer gas technique for measurement of methane and carbon dioxide production by cattle. Can. J. Anim. Sci. 82:125-131.

Carmean, B. R., and D. E. Johnson. 1990. Persistence of monensininduced changes in methane emissions and ruminal protozoa numbers in cattle. J. Anim. Sci. 68(Suppl.1):517. (Abstr.)

Chen, M., and M. J. Wolin. 1979. Effect of monensin and lasalocid sodium on the growth of methanogenic and rumen saccharolytic bacteria. Appl. Environ. Microbiol. 38:72-77.

Davies, A., H. N. Nwaonu, G. Stanier, and F. T. Boyle. 1982. Properties of a novel series of inhibitors of rumen methanogenesis: In vitro and in vivo experiments including growth trials on 2,4bis(trichlorometry)-benzo[1,3]dioxin-6-carboxylic acid. Br. J. Nutr. 47:565-576.

Duffield, T. F., and R. Bagg. 2000. Use of ionophores in lactating dairy cattle: A review. Can. Vet. J. 41:388-394.

Duffield, T. F., S. LeBlanc, R. Bagg, K. Leslie, J. Ten Hag, and P. Dick. 2003. Effect of a monensin controlled release capsule on metabolic parameters in transition dairy cows. J. Dairy Sci. 86:1171-1176.

Duffield, T. F., D. Sandals, K. E. Leslie, K. Lissemore, B. W. McBride, J. H. Lumsden, P. Dick, and R. Bagg. 1999. Effect of prepartum administration of a monensin controlled release capsule on milk production and milk components in early lactation. J. Dairy Sci. $82: 272-279$

Dye, B. E., H. E. Amos, and M. A. Froetschel. 1988. Influence of lasalocid on rumen metabolites, milk production, milk composition, and digestibility in lactating cows. Nutr. Rep. Int. 38:101-115.

Environment Canada. 2006. Greenhouse Gas Sources and Sinks in Canada 1990-2004. Available: http://www.ec.gc.ca/pdb/ghg/ inventory_report/2004/2004summary_e.pdf Accessed Oct. 20, 2006

Fellner, V., F. D. Sauer, and J. K. G. Kramer. 1997. Effect of nigericin, monensin, and tetronasin on biohydrogenation in continuous flow-through ruminal fermenters. J. Dairy Sci. 80:921-928.

Green, B. L., B. W. McBride, W. D. Sandals, K. E. Leslie, R. Bagg, and P. Dick. 1999. The impact of the monensin controlled release capsule upon subclinical ketosis in the transition dairy cow. J. Dairy Sci. 82:333-342.

Griinari, J. M., D. A. Dwyer, M. A. McGuire, D. E. Bauman, D. L. Palmquist, and K. V. V. Nurmela. 1998. Trans-octadecenoic acids and milk fat depression in lactating dairy cows. J. Dairy Sci. $81: 1251-1261$.

Guan, G., K. M. Wittenberg, K. H. Ominski, and D. O. Krause. 2006. Efficacy of ionophores in cattle diets for mitigation of enteric methane. J. Anim. Sci. 84:1896-1906.

Hayes, D. P., D. U. Pfeiffer, and N. B. Williamson. 1996. Effect of intraruminal capsules on reproductive performance and milk production of dairy cows fed pasture. J. Dairy Sci. 79:1000-1008.

Intergovernmental Panel on Climate Change. 2001. Climate Change 2001: Synthesis Report. A contribution of Working Groups I, II, and III to the Third Assessment Report of the Intergovernmental Panel on Climate Change. Cambridge University Press, Cambridge, UK.

Jenkins, T. C., V. Fellner, and R. K. McGuffey. 2003. Monensin by fat interactions on trans fatty acids in cultures of mixed ruminal microorganisms grown in continuous fermentors fed corn or barley. J. Dairy Sci. 86:324-330.

Johnson, K. A., and D. E. Johnson. 1995. Methane emissions from cattle. J. Anim. Sci. 73:2483-2492.

Johnson, K. A., H. H. Westberg, B. K. Lamb, and R. L. Kincaid. 1997. Quantifying methane emissions from ruminant livestock and examination of methane reduction strategies. The Rumin. Livest.
Efficiency Program Annu. Conf. Proc. US Environmental Protection Agency/USDA, Washington, DC.

Johnson, K. A., M. Huyler, H. H. Westberg, B. K. Lamb, and P. Zimmerman. 1994. Measurement of methane emissions from ruminant livestock using a $\mathrm{SF}_{6}$ tracer technique. Environ. Sci. Technol. 28:359-362.

Kelly, J. M., B. Kerrigan, L. P. Milligan, and B. W. McBride. 1994 Development of a mobile, open-circuit indirect calorimetry system. Can. J. Anim. Sci. 74:65-71.

Lean, I. J., M. Curtis, R. Dyson, and B. Lowe. 1994. Effects of sodium monensin on reproductive performance of dairy cattle. Effects on conception rates, calving to conception intervals, calving to heat and milk production in dairy cows. Aust. Vet. J. 71:273-277.

Maas, J. A., S. N. McCutcheon, G. F. Wilson, G. A. Lynch, M. E Hunt, and L. A. Crompton. 2002. Effect of monensin sodium on lactational performance of autumn- and spring-calving cows. J. Dairy Res. 69:317-323.

Mbanzamihigo, L., C. J. Van Nevel, and D. I. Demeyer. 1995. Essai sur l'adaptation fe la fermentation ruminale au monensin. Reprod. Nutr. Dev. 35:353-365.

Mbanzamihigo, L., C. J. Van Nevel, and D. I. Demeyer. 1996. Lasting effect of monensin on rumen and caecal fermentation in sheep fed a high grain diet. Anim. Feed Sci. Technol. 62:215-228.

McGinn, S. M., K. A. Beauchemin, T. Coates, and D. Colombatto. 2004. Methane emissions from beef cattle: Effects of monensin, sunflower oil, enzymes, yeast, and fumaric acid. J. Anim. Sci. 82:3346-3356.

McGuffey, R. K., L. F. Richardson, and J. D. Wilkinson. 2001. Ionophores for dairy cattle: Current status and future outlook. J. Dairy Sci. 84(E Suppl.):E194-E203.

McLean, J. A., and G. Tobin. 1987. Animal and Human Calorimetry. Cambridge University Press, New York, NY.

Moss, A. R., J.-P. Jouany, and J. Newbold. 2000. Methane production by ruminants: Its contribution to global warming. Ann. Zootech. 49:231-253

NRC. 2002. The scientific basis for estimating air emissions from animal feeding operations. National Academy Press, Washington, DC.

Odongo, N. E., O. AlZahal, J. E. Las, A. Kramer, B. Kerrigan, E. Kebreab, J. France, and B. W. McBride. 2007. Data capture: Development of a mobile open-circuit ventilated hood system for measuring real-time gaseous exchange in cattle. In Mathematical Modelling in Animal Nutrition. J. France and E. Kebreab, ed. CABI Publishing, Wallingford, UK. (In press)

Phipps, R. H., J. I. D. Wilkinson, L. J. Jonker, M. Tarrant, A. K. Jones, and A. Hodge. 2000. Effect of monensin on milk production of Holstein-Friesian dairy cows. J. Dairy Sci. 83:2789-2794.

Ramanzin, M., L. Bailoni, S. Schiavon, and G. Bittante. 1997. Effect of monensin on milk production and efficiency of dairy cows fed two diets differing in forage to concentrate ratios. J. Dairy Sci. 80:1136-1142.

Roe, M. B., C. J. Sniffen, and L. E. Chase. 1990. Techniques for measuring protein fractions in feedstuffs. Pages 81-88 in Proc. Cornell Nutr. Conf., Ithaca, NY.

Rogers, M., J. P. Jouany, P. Thivend, and J. P. Fontenot. 1997. The effect of short-term and long-term monensin supplementation, and its subsequent withdrawal on digestion in sheep. Anim. Feed Sci. Technol. 65:113-127.

Rumpler, W. V., D. E. Johnson, and D. B. Bates. 1986. The effect of high dietary cation concentrations on methanogenesis by steers fed with or without ionophores. J. Anim. Sci. 62:1737-1741.

Russell, J. B. 2002. Rumen microbiology and its role in ruminant nutrition. James B. Russell, Cornell Univ. Press, Ithaca, NY.

Russell, J. B., and A. J. Houlihan. 2003. The ionophore resistance ruminal bacteria and its potential impact on human health. FEMS Microbiol. Rev. 27:65-74.

Russell, J. B., and H. J. Strobel. 1989. Effect of ionophores on ruminal fermentation. Appl. Environ. Microbiol. 55:1-6.

Sauer, F. D., V. Fellner, R. Kinsman, J. K. G. Kramer, H. A. Jackson, A. J. Lee, and S. Chen. 1998. Methane output and lactation response in Holstein cattle with monensin or unsaturated fat added to the diet. J. Anim. Sci. 76:906-914. 
Steel, R. G. D., J. H. Torrie, and D. A. Dickey. 1997. Principles and Procedures of Statistics: A Biometrical Approach. 3rd ed. McGraw-Hill, New York, NY.

Tung, R. S., and L. Kung, Jr. 1993. In vitro effects of a thiopeptide and monensin on ruminal fermentation of soluble carbohydrates. J. Dairy Sci. 76:1083-1090.

Van der Werf, J. H. L., L. J. Jonker, and K. Oldenbroek. 1998. Effect of monensin on milk production by Holstein and Jersey cows. J. Dairy Sci. 81:427-433.
Van Nevel, C. J., and D. I. Demeyer. 1977. Effect of monensin on rumen metabolism in vitro. Appl. Environ. Microbiol. 34:251-257.

Van Soest, P. J., J. B. Robertson, and B. A. Lewis. 1991. Methods for dietary fiber, neutral detergent fiber, and nonstarch polysaccharides in relation to animal nutrition. J. Dairy Sci. 74:35833597.

Wilkerson, V. A., D. P. Casper, and D. R. Mertens. 1995. The prediction of methane production of Holstein cows by several equations. J. Dairy Sci. 78:2402-2414. 